\title{
METHODOLOGY OF SOLAR INSTALLATION DESIGN FOR WATER HEATING SYSTEM IN THE SWIMMING POOL IN TARNÓW
}

\author{
Anna WACHOWICZ-PYZIK \\ AGH University of Science and Technology, Faculty of Geology, \\ Geophysics and Environmental Protection, Department of Fossil Fuels; \\ al. A. Mickiewicza 30, 30-059 Krakow, Poland; \\ e-mail: amwachowicz@poczta.fm
}

\begin{abstract}
The aim of this article is to present designing methodology of solar installation for hot water, which allows us to determine the maximum benefit of a solar system. The complicated process of designing solar installation, is based mostly on the solar exposure conditions and hot water demand. Therefore, designing a particular solar system is a multi-objective task and should be performed carefully. Based on the proposed methodology, a conceptual model of the solar system for the swimming pool in Tarnów is presented. Designed solar installation was assumed to cover the demand of the object for domestic hot water consumption by $40 \%$ during the year. As a result, 270 vacuumtube solar collectors were selected. The various stages of the design of solar installations, as well as a detailed economic analysis with the determination of the profitability of investments in two variants are discussed. In both assumed variants the payback period was quite satisfactory. Also, the sensitivity analysis was conducted and the main factors affecting the return of investment were determined.
\end{abstract}

Key words: solar energy, solar installations, vacuum-tube collectors, renewable energy sources

\section{INTRODUCTION}

World energy demand is steadily increasing every year. Currently, the most widely used sources for energy purposes are: black coal, oil and natural gas, but their cost is continually rising. Furthermore, decreasing resources of nonrenewable sources and the state of environmental contamination is a problem for the entire energy sector. Particularly harmful to the environment is the emission of toxic gases such as $\mathrm{CO}_{2}, \mathrm{NO}_{\mathrm{x}}$, as well as heavy metal compounds whose elimination is difficult to achieve. The increase in interest of renewable energy sources, which are an alternative to the production of both heat and electricity, is not surprising. Their use is much faster, less harmful to the environment, and most of all their resources are practically unlimited. These include solar, wind, hydropower, biomass and also geothermal energy. 
Nowadays, the Renewable Energy Sector (RES) is treated as a priority, especially in those countries, which belong to the European Union (EU). This is demonstrated by numerous laws and various forms of funding, for investments, which use alternative energy sources. For example the Directive 2009/28/EC, the most important legislation in EU law, aims to increase the share of RES up to $20 \%$ of total energy consumption. In reference to the Directive all member countries are obliged to accept the National Action Plan in the field of using the unconventional sources of energy. In the case of Poland, this means an increase of RES share up to $15 \%$ by the end of the year 2020 .

Solar energy is one of the greatest and the most easily available sources of renewable energy in the world. The Sun provides energy to the Earth in the form of radiation. During the year, the energy reaches the Earth in the amount of $3.9 \cdot 10^{24} \mathrm{~J}$. It is the energy of more than 10,000 times greater than all the energy consumed at the same time on the Earth (Neupauer \& Magiera 2009). For the solar energy utilization purposes, the solar installations are designed. Accordingly, the Polish solar energy market has currently enormous variety of solar panels. Such a situation is illustrated by a large number of companies selling solar panels, and a large variety of different types of solar collectors available in the sales network throughout all of the country. Additionally, there is a number of economic instruments stimulating the projects propagating the renewable energy sources. Both, private investors and companies may rely on financial support in the form of grants subsidies, loans or loan guarantees.

With the growing popularity of solar systems in Poland, the problem of proper designing of solar installations is increasing. Due to the annual medium sunlight of the country and the average air temperature, solar installations are generally used for domestic hot water rather than heating. Regardless of the purpose, designing of a solar system should be carried out according to a specific methodology. That is why the knowledge about principles of operation of solar installations, and about solar energy is so important at the stage of designing. Moreover, the correct calculations, taking into consideration the optimal solution, allow us to obtain the highest profits for a particular investment, which is the most important information for the potential users.

\section{METHODOLOGY OF SOLAR INSTALLATION DESIGN}

There are several methods for designing a solar system. Some methods are proposed in the literature, others are based on computer simulations. Both of them are arduous processes which should begin with preliminary measurements and an insightful analyses of maps, diagrams, construction projects and the financial and economic analyzes. It is necessary to estimate the costs and benefits of the planned investment. The basic data which are needed at the design stage are: the amount of solar radiation (insolation), the possibility of location of the solar collectors (inclination) and to analyze the hot water requirement.

For the determination the basic sun energy condition in the region the parameters like solar radiation flux density $\mathrm{W} / \mathrm{m}^{2}$, insolation $\mathrm{kWh} / \mathrm{m}^{2}$ - the energy of solar radiation reaching the unit area at a certain time - and the number of sunshine hours of direct solar 
visible operation, are needed. The value of a solar radiation flux density is the amount of energy which the Earth receives per unit time, the generally accepted value of the global solar constant, which is commonly used to perform solar calculations, is $1367 \mathrm{~W} / \mathrm{m}^{2}$. For the Polish territory, insolation average changes from $833 \mathrm{kWh} / \mathrm{m}^{2}$ to about $1199 \mathrm{kWh} / \mathrm{m}^{2}$ per year (Zawadzki 2003).

After an evaluation of solar exposure conditions for the selected area and the method of utilization the designed solar installation, preliminary calculations for the proposed system can may proceed. One of the basic methods of solar installation designing is presented below (Fig. 1).

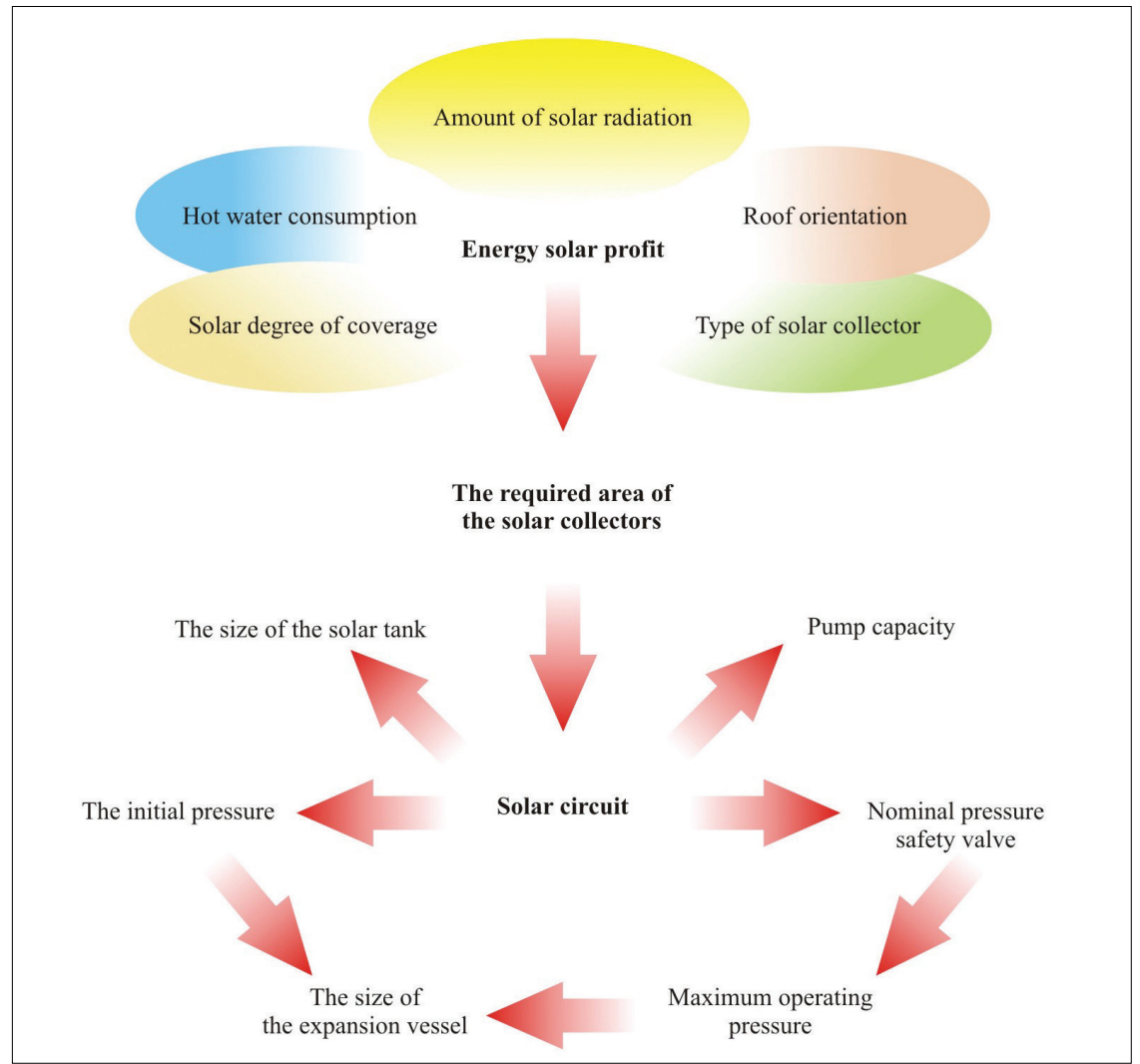

Fig. 1. The basic method of solar installation designing (based on Gruss \& Damm 2001)

Firstly, the degree of the solar coverage $(S F)$ must be determined. The solar coverage specifies the percentage which will be covered by the designed installation. $S F$ corresponds to the ratio of the annual energy solar profit $\left(Q_{S O L}\right)$ for domestic hot water demand $\left(Q_{B W}\right)$ and total of heat losses in a storage tank $\left(Q_{V S}\right)$ and circulation circuit $\left(Q_{V Z}\right)$. Depending on the type of the installation the $S F$ value is $40 \%, 60 \%$ or $80 \%$. Noteworthy is that the value 
of $S F$ is highly seasonal, in comparison with, both energy profit and heat losses which are constant during the year. From an economic point of view it is better to obtain the $S F$ at the level of $40-60 \%$. The size of the solar coverage, is shown below (Fig. 2).

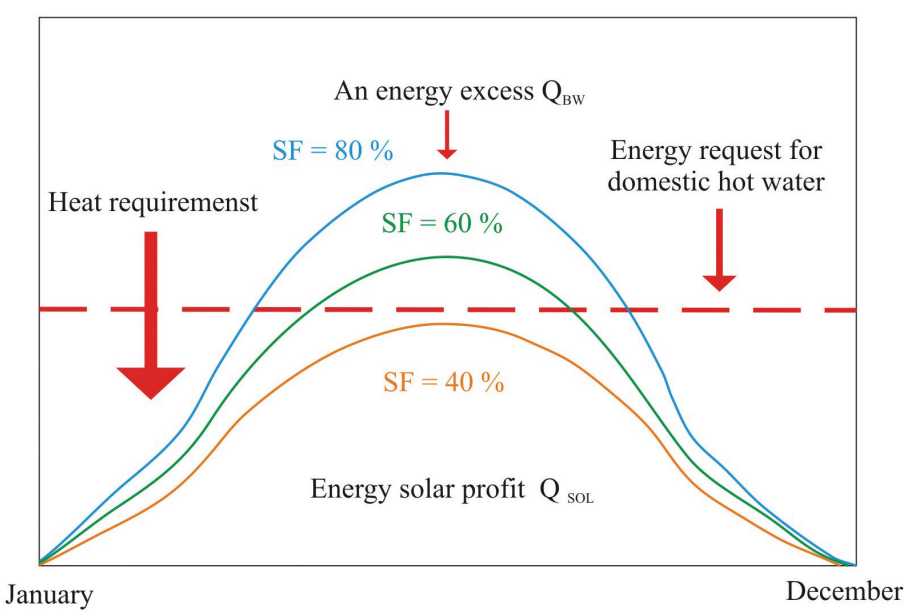

Fig. 2. The size of the solar coverage (based on Gruss \& Damm 2001)

On the basis of a facility's requirement for domestic hot water the amount of energy required for heating domestic hot water $\left(Q_{B W}\right)$ is estimated. The correct estimation allows for a selection of the type of the solar collector and the optimal area for the entire system. Subsequently, daily heat losses in the storage tank $\left(Q_{V S}\right)$ and into the circulating circuit $\left(Q_{V Z}\right)$, can be calculated. On the basis of the results, it is possible to estimate the energy required for the annual profit $\left(Q_{S O L}\right)$, which determines the necessary amount of energy produced by solar installations over the year to achieve the level of coverage, which was evaluated at the beginning of the design process. The formula for calculating the $Q_{S O L}$ is presented below (Gruss \& Damm 2001):

$$
Q_{S O L}=S F \cdot\left(Q_{B W}+Q_{V S}+Q_{V Z}\right) \cdot 365 / 1000 \mathrm{kWh} / \mathrm{year},
$$

were:

$Q_{S O L}$ - annual energy solar profit,

$S F$ - degree of solar coverage,

$Q_{B W}$ - daily energy required for heating or/ and domestic hot water purposes [Wh/d],

$Q_{V S}$ - daily heat losses in storage tank [Wh/d],

$Q_{V Z}$ - daily heat losses in circulating circuit [Wh/d],

365 - amount of days during the year,

$1000-1000 \mathrm{Wh}=1 \mathrm{kWh}$.

The energy required for the annual profit, allows for the selection of the adequate type of the solar collector, which enables us to calculate the required area of solar collectors, 
solar circuit, and finally the solar energy yield for the solar installation. Equally important factor is the optimal selection of the other elements included in the solar system such as: a solar storage tank, circulation pumps, and all the components necessary for the proper functioning of the entire system. These elements are usually chosen on the basis of the guidelines provided by solar collectors producers, based on preliminary calculations.

\section{BASIC ELEMENTS OF SOLAR INSTALLATION}

The most important elements included in the solar installation are the solar panels, which facilitate the energy production volume and ensure the efficiency of the entire system. A solar collector is a special kind of energy converter used to convert solar radiation energy into the thermal energy. The special fluid inside the solar collector having received heat from the solar radiation is sent to the heat exchanger where the fluid transfers heat to water, which is later sent to the consumer. The fluid can be either gas (e.g. air) or liquid (e.g. water, antifreeze). The key feature ensuring the collector high efficiency operation is also the thermal material (Zhang et al. 2007). Nevertheless, an important element is the solar storage tank - a tank, in which the thermal energy is stored. Due to the fact that energy from the sun is available for a few hours a day, and has high variability within the year, in order to increase the efficiency of solar installation the energy produced must be stored. Other necessary elements are also required, such as a pump that ensures fluid circulation inside the system, or security elements such as a safety valve and an expansion vessel. A simplified diagram of the solar system is presented below (Fig. 3).

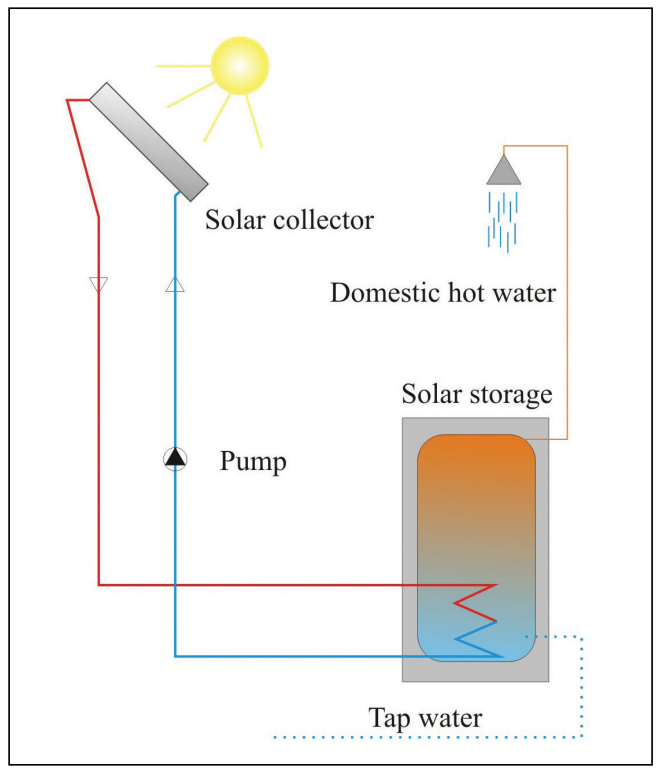

Fig. 3. The simplified diagram of the solar system for domestic hot water purposes (based on Gruss \& Damm 2001) 
One of the major factors which can significantly improve the size of the solar energy profit is the location of solar collectors. The angle between collector surface (aperture) and the sun rays is very important in order to collect solar energy. The collector aperture is the surface of the plane normal to the sun rays through which non-concentrated radiation enters the collector where it is reflected (Camacho et al. 2012).

In addition it is important to consider the optimal location of the solar collectors (Fig. 4). The orientations in accordance with the directions of the world and the optimum inclination angle are the most important factors which may significantly affect the future functioning of the whole system. At present the collectors are commonly located on the southern facade or a balcony (Xinian et al. 2009). Different variants of locations for solar collectors are shown in Figure 1 and the optimum inclination angle of the solar collector with regards to each months of the year is presented in Table 1.

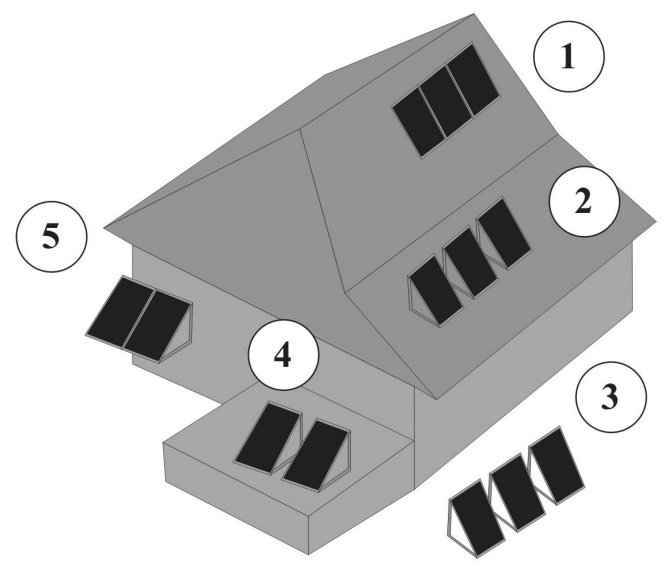

Fig. 4. Most common locations for solar collectors: 1 - embedded in the roof, 2 - on the sloping roof, 3 - on the ground, $4-$ on the flat roof, 5 - on the south building wall

Table 1

The values of the inclination angle with regards to each month during the year (Zawadzki 2003)

\begin{tabular}{|c|c|c|c|c|c|c|c|c|c|c|c|c|}
\hline Month & I & II & III & IV & V & VI & VII & VIII & IX & X & XI & XII \\
\hline $\begin{array}{c}\text { Inclination } \\
\text { angle [ }\left[^{\circ}\right]\end{array}$ & 60 & 55 & 45 & 30 & 15 & 10 & 15 & 30 & 45 & 55 & 65 & 65 \\
\hline
\end{tabular}

All parameters of the elements included in solar installations like the size of the solar storage tank, the pump capacity, and the size of the expansion vessel diameters must be appropriately selected. The designer must carefully calculate the fluid flow rate and thermal energy loss as these factors are necessary to determine the maximum pressure of the installation, and provide a basis for further selection of security features (e.g. security valves). 
The final stage of the solar system design is the preparation of a detailed estimation, financial analysis and the preliminary calculation of the approximate payback period.

\section{CONCEPTUAL MODEL OF SOLAR INSTALLATION}

Tarnow is a city situated in southern Poland, in the Małopolska province about $80 \mathrm{~km}$ from Cracow. The best evidence of very good insolation in Tarnów is the value of solar radiation, which in the southern part of our country reaches $1300 \mathrm{kWh} / \mathrm{m}^{2}$. The average annual number of hours of solar light in Tarnów over the past three decades was 1573 . Furthermore, since 2007 Tarnow has been referred to as "the warm south pole of the Eastern Poland." Based on the data presented above, it can be concluded that Tarnow has favorable conditions for the development of solar energy including the construction of facilities such as solar installations (Wachowicz 2011).

Based on the presented methodology and due to the data related to insolation in Tarnów, the conceptual model for the swimming pool TOSiR (Tarnów Sport and Recreation Center) was worked out. At the beginning of the design exercise the object was at the stage of rebuilding. The conceptual model was mainly focused on supporting domestic hot water while the excess energy was supposed to be used for reheating the water in the swimming pools. Due to the weak roof construction, the only feasible place for solar collectors was a plot belonging to the property owner. This plot, directed to the south, allowed for the optimal solar yield. Additional supporting construction was proposed to prevent crossshading of the solar collectors. The inclination angle of $45^{\circ}$ - which is suggested for the installation working throughout the entire year - was suggested. The designed solar installation was assumed to cover the demand of the object for domestic hot water consumption by $40 \%$ during the year. Taking into consideration the $40 \%$ coverage of energy consumption and the fact that the swimming pool works all year round the vacuum tube solar collectors which are recommended for that kind of investment - were chosen. The development of the existing heating system, where hot water preparation would be implemented in the threestep system was proposed. The first step of the water heating system was connected with the designed installation and the lack of the energy would be completed by Municipal Heating Company (MPEC), which is currently the only provider of the energy to the object.

The next step was to estimate the requirement for domestic hot water. Based on the data obtained from the investor and the property owner, the needs for the pool for domestic hot water were specified, as well as requirement for technological heat - necessary to heat water in the pools - both for the existing and also for the newly constructed building were estimated. Taking into account the data received from the property owner, the overall requirement, including the demand for domestic hot water and technological heat for calculations reached $613 \mathrm{~kW}$ for the existing building and $234 \mathrm{~kW}$ for the building under construction. The total demand for the entire facility reached $847 \mathrm{~kW}$, assuming the peak power. On the basis of energy consumption in 2009, the data were prepared by the energy provider MPEC (Wachowicz 2011), concerning the monthly consumption of heat for domestic hot water and technological water for the swimming pool during year 2009. Tables 2 and 3 clearly show the energy consumption in 2009. 
Table 2

Domestic hot water consumption in 2009

\begin{tabular}{|l|c|c|}
\hline Month & $\begin{array}{c}\text { Heat } \\
\text { consumption } \\
{[\mathrm{GJ}]}\end{array}$ & $\begin{array}{c}\text { Average daily } \\
\text { consumption } \\
{[\mathrm{GJ}]}\end{array}$ \\
\hline January & 632.80 & 20.41 \\
\hline February & 590.10 & 21.08 \\
\hline March & 723.34 & 23.33 \\
\hline April & 529.44 & 17.65 \\
\hline May & 301.63 & 9.73 \\
\hline June & 368.18 & 12.27 \\
\hline July & 295.12 & 9.52 \\
\hline August & 416.10 & 13.42 \\
\hline September & 516.95 & 17.23 \\
\hline October & 428.59 & 13.83 \\
\hline November & 508.93 & 16.96 \\
\hline December & 556.90 & 17.96 \\
\hline Summary & 5868.09 & - \\
\hline Daily average & - & 16.12 \\
\hline
\end{tabular}

Table 3

Technological heat consumption in 2009

\begin{tabular}{|l|c|c|}
\hline Month & $\begin{array}{c}\text { Heat } \\
\text { consumption } \\
{[\mathrm{GJ}]}\end{array}$ & $\begin{array}{c}\text { Average daily } \\
\text { consumption } \\
{[\mathrm{GJ}]}\end{array}$ \\
\hline January & 121.92 & 3.93 \\
\hline February & 119.74 & 4.28 \\
\hline March & 121.92 & 3.93 \\
\hline April & 159.48 & 5.32 \\
\hline May & 124.37 & 4.01 \\
\hline June & 72.12 & 2.40 \\
\hline July & 94.98 & 3.06 \\
\hline August & 86.00 & 2.77 \\
\hline September & 78.65 & 2.62 \\
\hline October & 104.23 & 3.36 \\
\hline November & 103.41 & 3.45 \\
\hline December & 100.15 & 3.23 \\
\hline Summary & 1286.96 & - \\
\hline Daily average & - & 3.53 \\
\hline
\end{tabular}


For a better understanding the results, the difference between energy consumption of domestic hot water and technological water has been presented in Figure 5.

\section{Energy consumption in 2009}

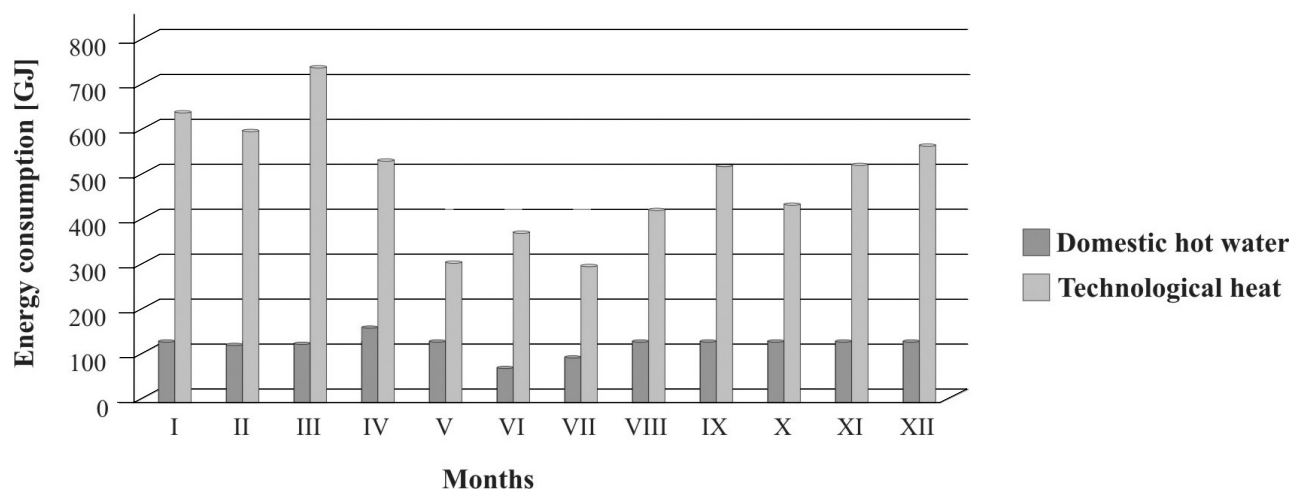

Fig. 5. The energy consumption in 2009

It can be easily seen that the requirement for technological heat greatly exceeds the requirement for domestic hot water. In addition, the seasonal increase in demand for thermal power during winter months - from October to March - which reached around $100 \mathrm{GJ} /$ month - may be noticed, as well as a decrease in the energy consumption in summer down to an average of $50 \mathrm{GJ} / \mathrm{month}$ from April to September. A large increase in power consumption, which reached about $700 \mathrm{GJ}$ in March, was associated with the failure of the pool.

In order to determine the daily energy consumption, additional research was conducted. The research was carried out for three months from March to May and mostly aimed at recording certain parameters. The observed parameters such as flow rate, temperature at the inlet and outlet of the tank and many others, including the amount of people using the facility per hour every day from the start to the end of swimming pool operation. With reference to the study it may be concluded that the greatest need for energy for the object in question is observed from 9 am to $11 \mathrm{am}$ and then from $1 \mathrm{pm}$ to $5 \mathrm{pm}$, which corresponds to the increase in the number of people using the facility.

Taking into account the requirement for domestic hot water and technological water for both indoor swimming pool facilities 270 vacuum-tube solar collectors were selected, with a total area of $604.8 \mathrm{~m}^{2}$ and the $324 \mathrm{~m}^{2}$ of the active surface. Considering also the existing system and reconstructed installations, domestic hot water preparation will be carried out in a three-step system. The proper functioning of the installation will be ensured by rotameters for $2-15$ flow $\mathrm{dm}^{3} / \mathrm{min}$ placed in front of each set consisting of three collectors. 
The technological system will use indirect fluid due to the large total surface area of collectors, ban direct contact with drinking water solar factor water-glycol $30 \%$ in the swimming pool facilities and the need to use a large buffer capacity (Wachowicz 2011).

\section{THE COST-EFFECTIVENESS AND PAY-BACK PERIOD}

In order to determine the cost-effectiveness of the investment, a detailed cost estimation was performed. The calculated amount (gross cost) of the investment reached approximately 1500,000 PLN. The share of the cost of each item is shown in Figure 6. As it can be seen from this chart the major investments are related to the devices included in the installation (Wachowicz 2011).

\section{Cost estimation}

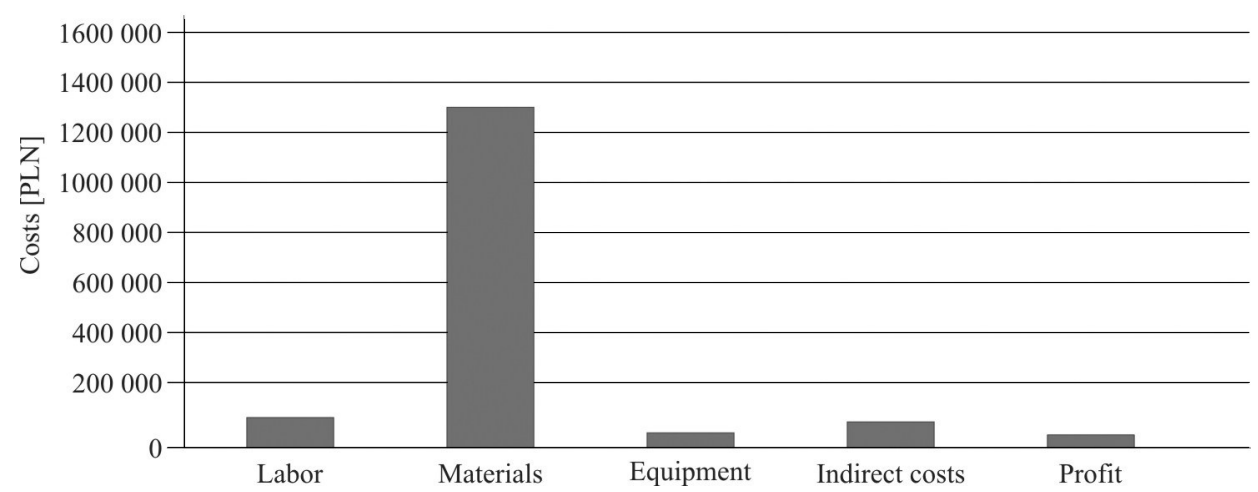

Fig. 6. Gross cost statment for items included in the proposed solar installation

Additionally, the payback period analysis was prepared in two variants: with $80 \%$ of funding from the Malopolska Regional Operational Programme 2007, and without funding. The cost-effectiveness analysis was performed assuming energy costs of 24 PLN per 1 GJ at 15\% price increase in the coming years. Figure 7 shows the pay-back period at $80 \%$ of funding.

The payback period of the investment with funding took about 9 years, which is a very good result for such a large investment. Carrying out simulations without subsidies (Fig. 8) increases the payback period to about 18 years, which is quite satisfactory considering the fact that after 25 years, the expected return on investment nearly doubled.

Finally, a sensitivity analysis was also performed and the degree of risk (using IRR) on the account of efficiency investments was also determined. The method of sensitivity analysis was carried out for different types of investments and investment effects, which are 
the basic elements of economic calculation for the solar system and they include: fuel costs, interest rates on debt, term debt and the rate of operation of the installation itself. The results obtained are shown in Figure 9.

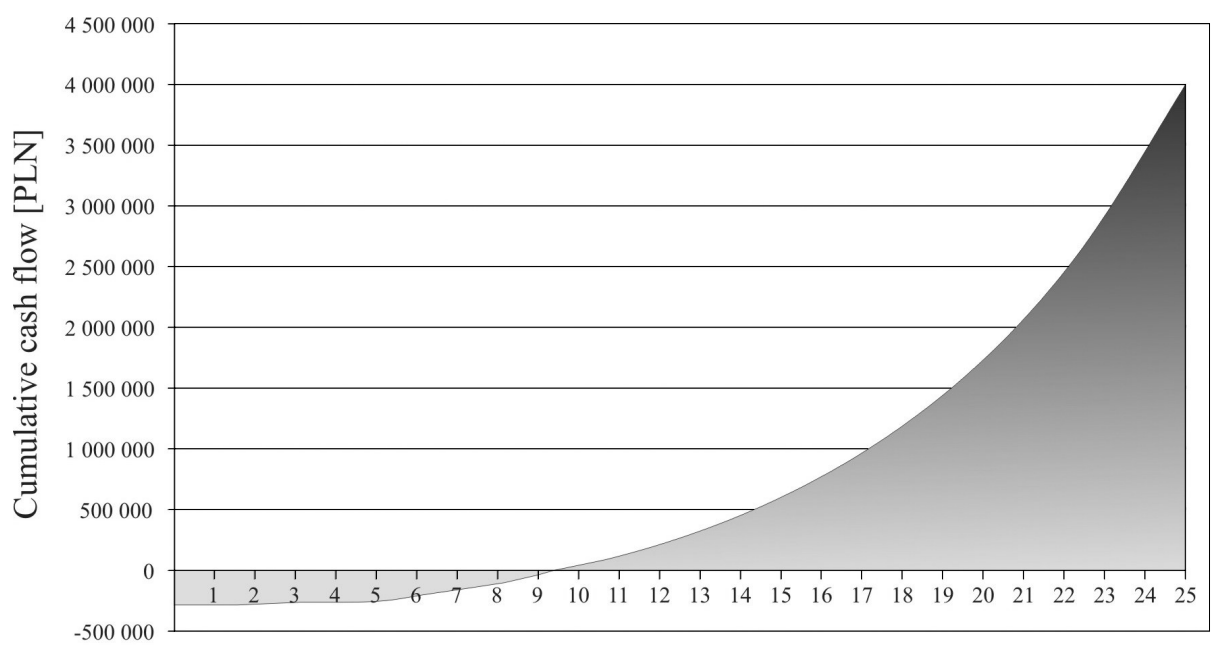

Year

Fig. 7. Figure of the cumulative cash flow with $80 \%$ funding

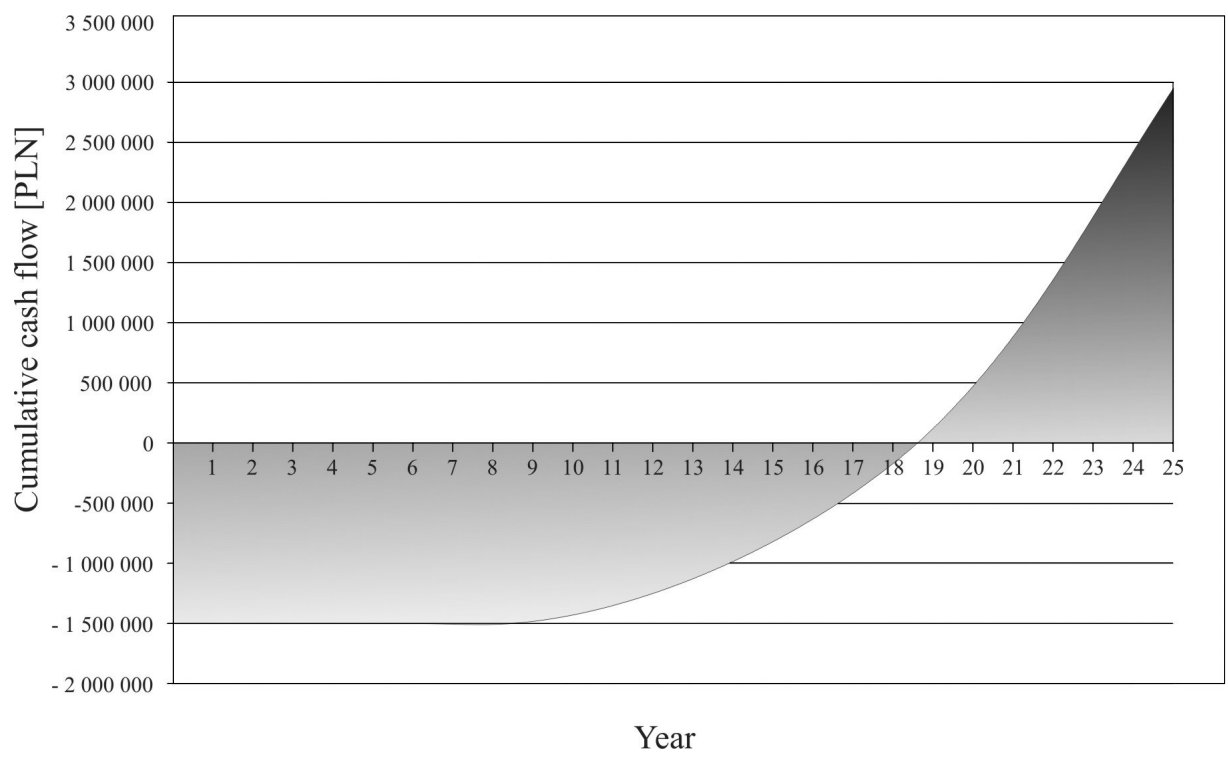

Fig. 8. Figure of the cumulative cash flow without founding 


\section{The relative influence of parameter variability index}

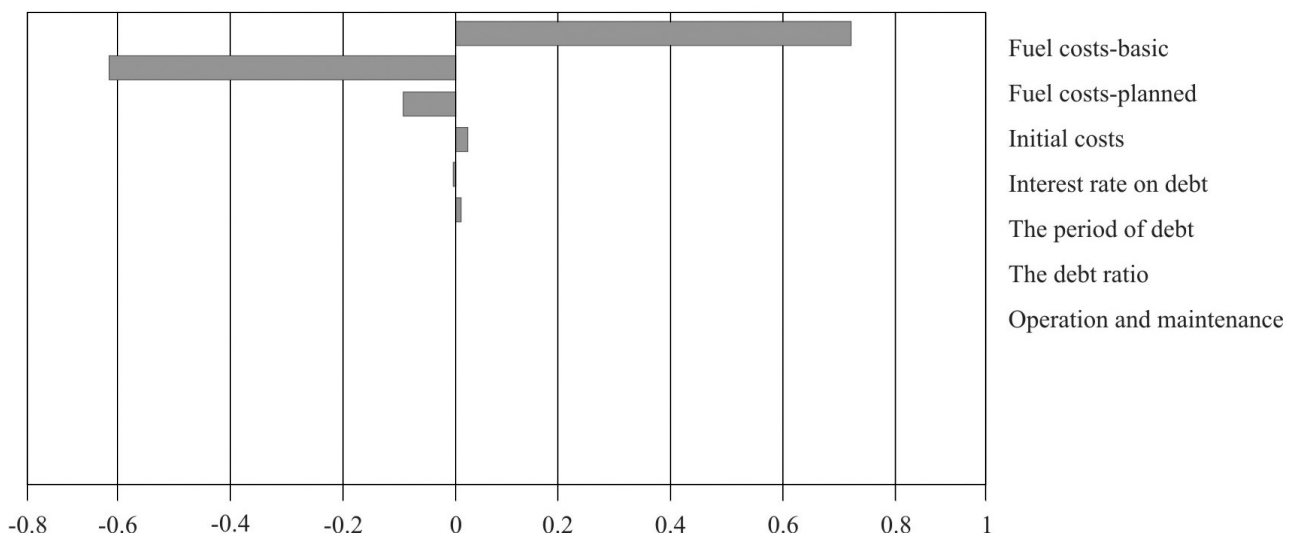

Fig. 9. Investment risk analysis carried out on the basis of IRR in Reetscreen

Based on the parameter analysis, the greatest influence on the efficiency of the project was indicated. The greatest impact on the rate of payback period was the price of fuel. In comparison, the operation and maintenance will have only a marginal impact on the economical aspects of the investment (Wachowicz 2011).

\section{CONCLUSION}

Based on the proposed methodology, it may be concluded that, the conceptual model of a solar installation, has economical and ecological justification. Unfortunately, despite the fact that the investment could significantly reducde the costs of energy and toxic emissions such as $\mathrm{CO}_{2}$ and $\mathrm{NO}_{\mathrm{x}}$, which are released during the combustion of conventional fuels, so far the designed solar installation remained at the project stage. Furthermore, such a large investment in the renewable energy sector can help us achieve the financial benefits in the future. Finally, it is to be hoped that it will be implemented in the future. However, particular attention should be paid to appropriate methods applied in the process of designing, because only in this case, the project will be effective and profitable.

The author would like to thank Mr Mirostaw Janowski for all help in preparing this paper, the Director of TOSiR in Tarnów, the representative of the MPEC in Tarnów for providing the materials useed and Mr Michat Stefaniuk for motivation to publish this article. 


\section{REFERENCES}

Camacho E.F., Berenguel M., Rubio F.R. \& Martinez D., 2012. Control of Solar Energy Systems. [in:] Advances in Industrial Control, Springer-Verlag, London, 25-47.

Gruss B. \& Damm G., 1997. Schulung Photovoltaik: Beratung, Planung, Installation. Förderverein für Neue Technik, Photovoltaik und Regenerative Energien im Handwerk [Polish translation: Kacprzak M. \& Raganowicz G., 2001. Energia słoneczna: termalne instalacje grzewcze, doradztwo, planowanie, instalowanie. Powiatowe Centrum Kształcenia Praktycznego w Bielawie].

Magiera J. \& Neupauer K., 2009. Efficiency analysis of different types of solar collectors. Technical Transactions, 4, 106, 58-65.

Małopolski Regionalny Program Operacyjny na lata 2007-2013 Załacznik Nr 1 do Uchwaty Nr 780/07 Zarzqdu Województwa Małopolskiego z dnia 4 października 2007 r. w sprawie przyjęcia Małopolskiego Regionalnego Programu Operacyjnego na lata 2007-2013, 2007. Zarząd Województwa Małopolskiego, Kraków.

Wachowicz A., 2011. Koncepcyjny projekt instalacji solarnej dla basenu TOSIR w Tarnowie. Wydział Geologii, Geofizyki i Ochrony Środowiska AGH, Kraków [unpublished].

Xinian J., Hongchauan G. Hanshan G. \& Xiaobo Z., 2009. Horizontal heat pipe vacuum tube collectors application in Balcony solar water heater. Proceedings of ISES World Congress 2007, I-V, 571-574.

Zawadzki M. (red.), 2003. Kolektory słoneczne, pompy ciepta - na tak. Polska Ekologia, Warszawa.

Zhang J., Huang H. \& Zhang J., 2007. Experimental study on solar collector with different thermal storage materials. Challenges of Power Engineering and Environment, 11551157. 
